\title{
PENGEMBANGAN SISTEM INFORMASI UNTUK MENENTUKAN HARGA POKOK PENJUALAN (STUDI KASUS : TOKO KUE RANIA)
}

\author{
Andi Muh Haekal Raflie, Karina Auliasari, Renaldi Primaswana P \\ Program Studi Teknik Informatika S1, Fakultas Teknologi Industri \\ Institut Teknologi Nasional Malang, Jalan Raya Karanglo km 2 Malang, Indonesia \\ Rafliehaekal@gmail.com
}

\begin{abstract}
ABSTRAK
Toko kue Rania adalah sebuah toko kue yang berada di kota Makassar. Pada proses penjualan kue, pemesanan dan penjualan kue dicatat secara manual ke dalam sebuah buku, begitupun dalam proses penjualan, transaksi juga dihitung, dan ditulis dalam nota penjualan secara manual. Selain itu karena besar kecilnya harga produksi tergantung pada harga bahan baku. Terkadang harga bahan baku juga mengalami kenaikan maupun penurunan, hal ini juga menyebabkan pemilik kesulitan untuk menentukan harga jual kue.

Perlu adanya sebuah aplikasi yang dapat membantu pengelolaan penjualan toko dan menentukan harga jual dengan mengetahui harga pokok produksi kue secara tepat. Dari permasalahan ini penulis membuat sebuah program aplikasi yang dapat membantu toko kue Rania dalam operasional toko kue berupa sistem informasi akuntansi berbasis web yang dilengkapi dengan metode HPP (harga pokok produksi) yang dapat membantu dalam hal penentuan harga jual kue.

Dari hasil pengujian user dapat disimpulkan bahwa sistem informasi akuntasi berbasis website menggunakan metode HPP pada toko kue Rania ini bermanfaat bagi kinerja toko kue Rania dalam melakukan kegiatan pembelian, penjualan, perhitungan harga dan juga laporan kas arus serta laporan penjualan.
\end{abstract}

\section{Kata kunci : HPP, Toko Kue, Sistem Informasi Akuntasi}

\section{PENDAHULUAN}

Rania Cake merupakan sebuah toko kue yang berlokasi di Jalan Ade Irma Nasution 2 no 12 , kelurahan Ujung Pandang Baru, kecamatan Tallo, kota Makassar, Sulawesi Selatan. Toko ini menjual berbagai macam dan jenis kue. Sama seperti toko maupun usaha lainnya dalam bidang perdagangan pasti memiliki proses bisnis yang hampir sama.

Berdasarkan pelaksanaan pengamatan yang telah dilakukan, toko kue Rania Cake memiliki proses bisnis tersendiri, yang dalam kegiatan sehari-hari dilakukan secara manual, khususnya pada bagian penjualan. Pada proses penjualan kue, pemesanan dan penjualan kue dicatat secara manual ke dalam sebuah buku tulis, begitupun dalam proses penjualan, transaksi juga dihitung, dan ditulis dalam nota penjualan manual. Selanjutnya data dalam nota penjualan tersebut dikumpulkan untuk dilakukan perekapan data ke dalam buku besar penjualan pada akhir jam kerja atau keesokan harinya, namun hanya transaksi masuk saja yang dituliskan pada buku penjualan. Hal tersebut dinilai kurang efisien karena tidak tercatatnya arus kas secara benar, dan aktifitas tersebut dilakukan secara berulang. Dan karena besar kecilnya biaya produksi tergantung pada harga bahan baku. Terkadang harga bahan baku juga mengalami kenaikan dan penurunan harga, hal ini juga menyebabkan pemilik kesulitan untuk menentukan harga jual kue.

Permasalahan-permasalahan itu tentunya akan berdampak buruk dalam proses bisnis toko kue Rania Cake. Perlu adanya sebuah aplikasi yang dapat membantu pengelolaan penjualan toko dan menentukan harga jual dengan mengetahui harga pokok produksi kue secara tepat dan akurat.

Oleh karena itu, penulis melakukan penelitian ini dengan judul "Pengembangan Sistem Informasi Untuk Menentukan Harga Pokok Penjualan (Studi Kasus : Toko Kue Rania)".

\section{TINJAUAN PUSTAKA \\ 2.1 Penelitian Terdahulu}

Sistem adalah sekelompok unsur yang memiliki hubungan antara satu dengan yang lainnya yang dipergunakan secara bersamaan untuk mencapai tujuan tertentu, dan sistem memiliki banyak unsur yang berfungsi untuk mencapai tujuan yang sama.[1]

Sistem informasi akuntansi adalah cara untuk menggabungkan dan mengolah informasi keuangan yang efisien, yang dilakukan daam rangka untuk membantu pengambilan keputusan pihak-pihak yang terkait dalam proses pengoalahn keuangan tersebut. Sistem informasi keuangan juga berfungsi sebagai sarana pengendalian keuangan agar perusahaan dapat menghindari segala resiko kerugian. Selain itu sistem informasi keuangan memiliki fungsi manajemen yang bertujuan agar segala aktivitas perusahaan berjalan sesuai dengan perencanaan yang telah ditetapkan ${ }^{[2]}$.

Penyimpangan dari rencana awal merupakan unsur yang harus dihindari karena akan menimbulkan kerugian sumber daya yang akan mengurangi kemampuan financial perusahaan. Apabila kekurangan tersebut terus berlanjut tanpa diatasi, dapat dipastikan bahwa perusahaan bersangkutan tidak akan dapat bertahan lebih lama lagi. Oleh karena itu penerapan sistem informasi akuntansi yang efektif dalam suatu perusahaan akan memberikan 
banyak manfaat bagi perusahaan dan manajemen dalam menjalankan usaha. ${ }^{[3]}$

Sistem informasi akuntasi dalam hal bisnis adalah formulir, catatan, dan laporan yang dikelola sedemikian rupa untuk menyediakan informasi keuangan yang dibutuhkan oleh manajemen guna memudahkan pengelolaan usaha. Terdiri atas formulir, catatan-catatan, dan prosedur-prosedur yang digunakan untuk menyediakan dan mengolah data keuangan yang berfungsi sebagai media kontrol bagi manajemen untuk mendukung pengambilan keputusan bisnis. ${ }^{[4]}$

\subsection{Dasar Teori}

\subsubsection{Sistem Informasi}

Sistem Informasi merupakan hasil dari kerjasama antara perangkat keras, perangkat lunak dan perangkat manusia dalam pengolahan data. Sistem informasi merupakan sistem buatan otak manusia dan terdiri atas komponen yang terkoordinasi menjadi satu yang digunakan untuk mengumpulkan, menyimpan, dan mengelola data serta menyediakan informasi kepada pengguna yang berkepentingan sebagai pemakai informasi tersebut.

[5]

Sistem informasi juga memiliki beberapa komponen, yaitu input atau masukan, model, output atau keluaran, teknologi, basis data dan control atau pengendalian. ${ }^{[6]}$

\subsubsection{Sistem Informasi Akuntansi}

Sistem informasi akuntansi adalah sekumpulan catatan, perangkat komputer dan perlengkapannya sebagai alat komunikasi, sarana, proses, dan laporan terkoordinasi secara akurat yang didesain untuk merubah data keuangan menjadi informasi yang dibutuhkan. Sistem informasi juga suatu komponen organisasi yang mengumpulkan dan memproses informasi yang dibutuhkan salam sebuah usaha ${ }^{[7]}$

Sistem informasi akuntansi juga merupakan kumpulan informasi dari, catatan, manusia dan sumber informasi lainnya dalam perusahaan, yang bertanggungjawab untuk menyediakan informasi keuangan dan juga informasi yang didapat dari pengumpulan dan pengolahan data transaksi. Dapat disimpulkan bahwa sistem informasi akuntansi merupakan suatu sistem yang terdiri dari input berupa data transaksi keuangan yang kemudian diproses menjadi suatu output berupa laporan yang memberikan informasi mengenai keuangan. ${ }^{[8]}$

\subsubsection{Harga Pokok Produksi}

Harga pokok produksi adalah biaya operasional yang telah dikeluarkan untuk satu periode produksi.

Harga pokok produksi terdiri dari biaya bahan baku, biaya tenaga kerja langsung, dan biaya overhead pabrik.

Berikut ini pengertian biaya bahan baku, biaya tenaga kerja langsung, dan biaya overhead pabrik.
1. Biaya Bahan Baku. Biaya bahan baku adalah biaya yang membentuk bagian menyeluruh produk jadi. Hal - hal yang perlu diperhatikan dalam biaya bahan baku, yaitu :

a. Unsur \pm unsur yang membentuk biaya bahan baku. Merupakan biaya yang dikeluarkan untuk memperoleh bahan baku untuk siap diproses.

Unsur pembentuk biaya bahan baku terdiri dari

a.) Potongan pembelian.

b.) Ongkos angkut bahan baku

b. Penentuan biaya bahan baku yang dipakai dalam produksi. Pembelian bahan baku dari waktu ke waktu selalu mengalami perubahan, oleh karena itu diperlukan suatu metode dalam pemakaian bahan baku agar biaya yang dibebankan menjadi akurat.

c. Masalah khusus yang berhubungan dengan biaya bahan baku adalah sisa bahan. Dalam proses produksi tidak semua bahan baku dapat diolah menjadi produk jadi. Sisa bahan merupakan bahan baku yang rusak dalam proses produksi, sehingga tidak dapat menjadi bagian produk jadi.

2. Biaya Tenaga Kerja Langsung. Biaya tenaga kerja langsung adalah balas jasa yang diberikan pada karyawan pabrik yang manfaatnya dapat diidentifikasikan atau diikuti jejaknya pada produk tertentu yang dihasilkan perusahaan

3. Biaya Overhead Pabrik. Biaya overhead pabrik adalah biaya produksi selain biaya bahan baku dan biaya tenaga kerja langsung.

4. Barang dalam Proses. Barang dalam proses adalah barang yang belum jadi atau barang yang tingkat penyelesaian belum 100\%. Barang dalam proses ada dua kategori, yaitu : barang dalam proses awal dan barang dalam proses akhir. ${ }^{[9]}$.

\section{METODE PENELITIAN}

\subsection{Analisis Kebutuhan}

1. Analisis Kebutuhan Fungsional

Dalam aplikasi sistem informasi akuntansi berbasis web ini mempunyai struktur sistem yang harus dijelaskan untuk menjabarkan analisis sistem untuk mengetahui kebutuhan yang harus dipenuhi sebagai berikut :

Pengguna sistem adalah Admin maka terdapat fitur yang harus dipenuhi, berikut diantaranya:

a. Admin dapat melihat data master kue dan bahan, perhitungan HPP, laporan pembelian dan penjualan.

b. Admin dapat menambah data master kue, master bahan, perhitungan HPP, pembelian dan penjualan.

c. Admin dapat menghapus data master kue, master bahan, perhitungan HPP, pembelian dan penjualan.

d. Admin dapat mengubah data master kue, master bahan, perhitungan HPP, pembelian dan penjualan.

e. Admin dapat melihat hasil dari perhitungan HPP. 


\section{Analisis Kebutuhan Non-Fungsional}

Kebutuhan non-fungsional merupakan kebutuhan diluar fungsi dari sistem yang tidak berhubungan dengan kinerja sistem. Berikut ini merupakan beberapa kebutuhan non-fungsional dari sistem informasi akuntansi ini :

a. Sistem memiliki halaman yang dijalankan oleh admin.

b. Sistem memiliki tampilan window responsive yang dapat tampil maksimal dalam berbagai macam ukuran layar jendela browser.

c. Sistem dapat dijalankan oleh beberapa software web browser diantaranya Internet Explore, Google Chrome dan Mozilla Firefox.

d. Sistem memiliki tampilan antarmuka yang mudah dipahami.

e. Sistem dapat diakses darimana saja.

f. Sistem dapat dioperasikan oleh siapa saja yang sebagai

admin.

\subsection{Flowchart Sistem}

Adapun alur proses penjualaan kue dijelaskan pada gambar 3.1

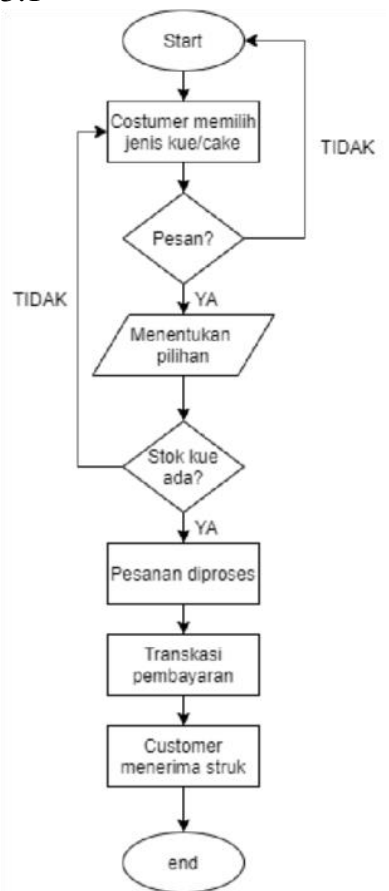

Gambar 3.1 Flowchart Sistem

Gambar 3.1 tersebut menunjukan alur yang berjalan dalam proses bisnis toko kue Rania Cake. Yang diawali dengan pelanggan memilih jenis kue, maupun melakukan pemesanan kue, setelah proses tersebut selesai maka akan ada proses lanjutan yaitu pesanan diproses, dan setelah selesai pelanggan dapat melakukan pelunasan pembayaran kepada kasir, dan mendapatkan struk atau nota.

\subsection{Perhitungan Harga Pokok Produksi}

Adapun cara perhitungan harga pokok produksi dijelaskan seperti cara dibawah ini :

a. Laporan / Data Produksi :

- Produk masuk proses xxxx (satuan)

- Jumlah Produk yang diproses Xxxx (satuan)

b. Biaya yang dibebankan :

Tabel 3.1 Tabel perhitungan

\begin{tabular}{|l|c|c|c|}
\hline $\begin{array}{c}\text { Elemen } \\
\text { Biaya }\end{array}$ & $\begin{array}{c}\text { Jumlah } \\
\text { Biaya }\end{array}$ & $\begin{array}{c}\text { Jumlah } \\
\text { Produksi }\end{array}$ & HP/Unit \\
\hline BBB & $\mathrm{x}$ & $\mathrm{x}$ & $\mathrm{x}$ \\
\hline $\begin{array}{l}\text { BTKL } \\
\text { BTKTL }\end{array}$ & $\mathrm{x}$ & $\mathrm{x}$ & $\mathrm{x}$ \\
\hline BOP & $\mathrm{x}$ & $\mathrm{x}$ & $\mathrm{x}$ \\
\hline $\begin{array}{l}\text { Total B } \\
\begin{array}{l}\text { iaya } \\
\text { Produksi : }\end{array}\end{array}$ & $\mathrm{x}$ & $\mathrm{x}$ \\
\hline
\end{tabular}

Ket :

1. BBB : Biaya Bahan Baku

2. BTKL : Biaya Tenaga kerja Langsung / Tidak Langsung

3. BOP : Biaya Overhead Pabrik (Dapat juga ditambahkan biaya penyusutan)

c. Perhitungan Harga Jual Harga jual = (Biaya $\mathrm{HP} /$ Unit $)+(\%$ margin laba $\mathrm{x}$ biaya produksi $)$

\subsection{DFD Level 0 dan Level 1}

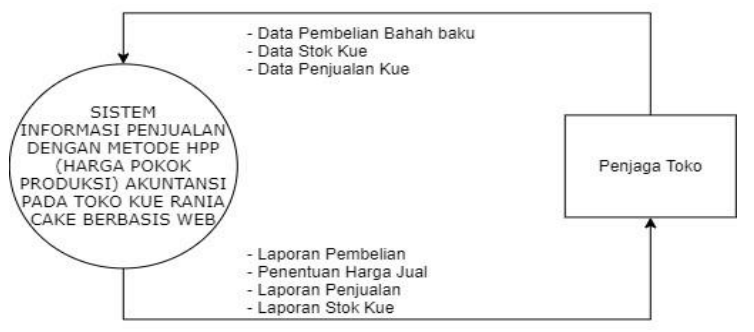

Gambar 3.2 DFD Level 0

DFD Level 0 tersebut menggambarkan bahwa ada 1 pelaku yang terdapat di dalam sistem yaitu penjaga toko. Penjaga toko menjadi pihak yang mengelola basis data pengetahuan yang ada.

Untuk lebih terperinci, DFD akan dipecah lagi menjadi level 1, DFD level 1 dilihat pada Gambar 3.3. 


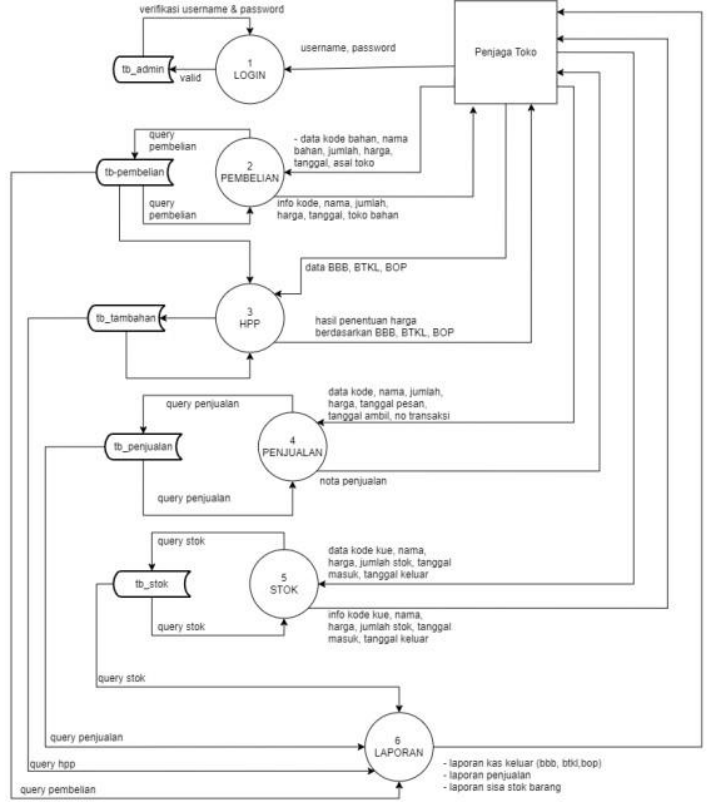

Gambar 3.3 DFD Level 1

Diagram level 1 di atas menggambarkan bahwa pada website ERP berbasis web ini terdapat 6 proses yaitu proses 1 login, proses 2 pembelian bahan baku, proses 3 pengoalah HPP, proses 4 penjualan, proses 5 stok dan proses 6 laporan. Setiap proses diperjelas dengan diagram rincian. Dimana setiap diagram memiliku fungsinya masing-masing.

\section{HASIL DAN PEMBAHASAN}

\subsection{Hasil Implementasi}

4.1.1 Halaman Login

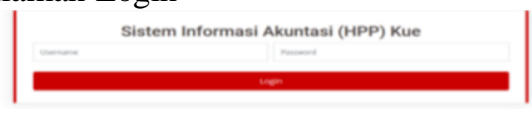

Gambar 4.1 Halaman Login

Halaman login ini merupakan tampilan awal

(user) harus melakukan login terlebih dahulu kemudian dapat masuk ke dalam halaman utama (home). Halaman login tersebut seperti ditunjukkan pada gambar 4.1.

4.1.2 Halaman Master Input Data Bahan

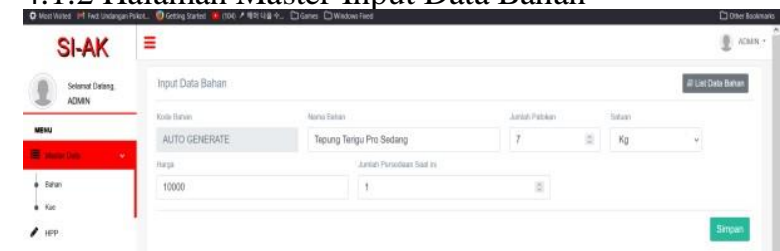

Gambar 4.2 Halaman Master Input Data Bahan

Halaman master input data bahan merupakan ketika aplikasi ini dijalankan. Sehingga pengguna form yang digunakan untuk menyimpan data bahan yang terdiri atas nama bahan, kuantitas, satuan, harga dan persediaan bahan saat ini. Admin dapat menginputkan data bahan dan minyimpan data tersebut dengan menekan tombol simpan seperti ditunjukkan pada gambar 4.2.
4.1.3 Halaman List Data Bahan

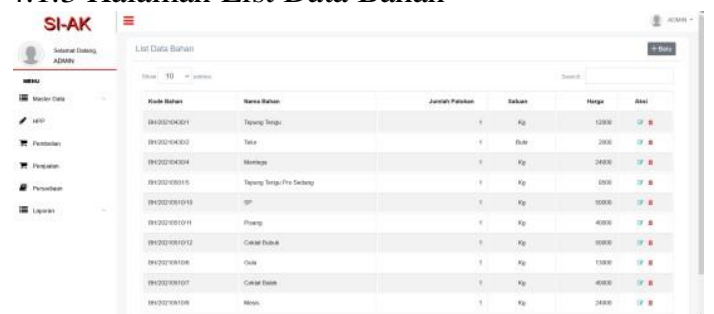

Gambar 4.2 Halaman List Data Bahan Pada gambar 4.2 menampilkan list data bahan.

4.1.4 Halaman Master Input Data Kue

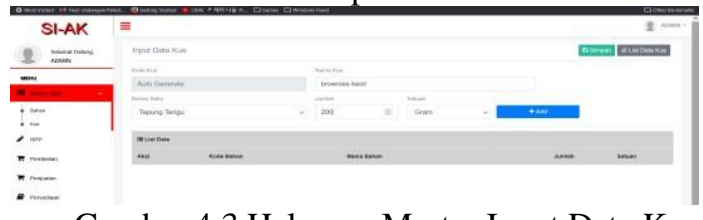

Gambar 4.3 Halaman Master Input Data Kue

Pada gambar 4.3 merupakan halaman master input data kue dimana user dapat menginputkan nama kue, bahan-bahan pembuat kue dan dapat didimpan dengan menekan tombol simpan.

\subsubsection{Halaman List Data Kue}

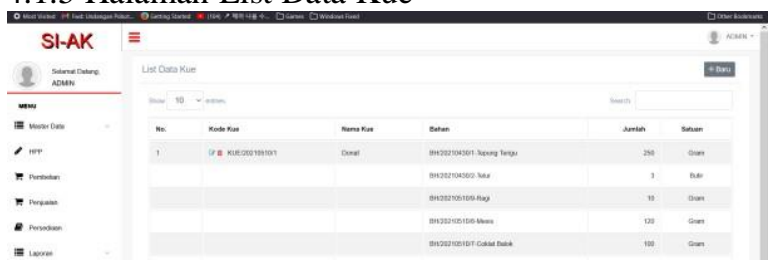

Gambar 4.4 Halaman List Data Kue

Pada gambar 4.4 merupakan list data kue yang menyimpan informasi mengenai jenis kue yang ada pada toko kue, menyimpan informasi kode kue, nama kue, bahan, jumlah dan satuan.

\subsubsection{Halaman Perhitungan HPP}

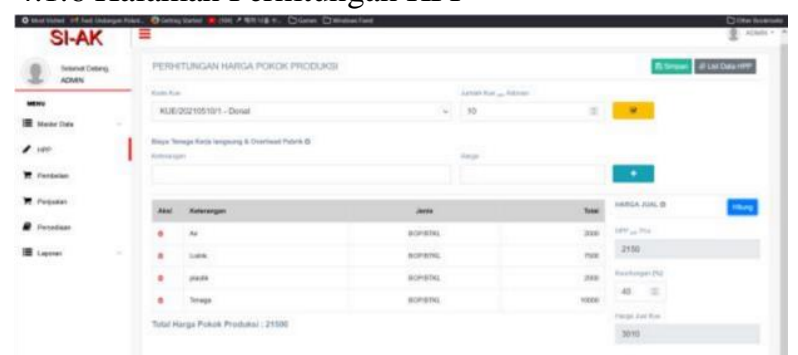

Gambar 4.5 Halaman perhitungan HPP

Pada gambar 4.5 merupakan halaman perhitungan HPP yang dapat digunakan oleh user untuk menghitung HPP dengan menginputkan kode

kue, jumlah kue per-adonan, biaya lainnya, keuntungan dan akan langsung terhitung dengan menekan tomnol hitung.

\subsubsection{Halaman List Data HPP}




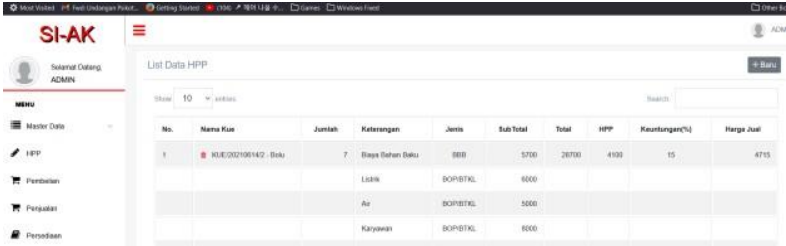

Gambar 4.6 Halaman List HPP

Pada gambar 4.6 merupakan halaman list data HPP yang menyimpan hasil perhitungan HPP mencakup informasi nama kue, keterangan, jenis, sub total, total, HPP, keuntungan, dan harga jual.

\subsubsection{Halaman Input Data Pembelian}

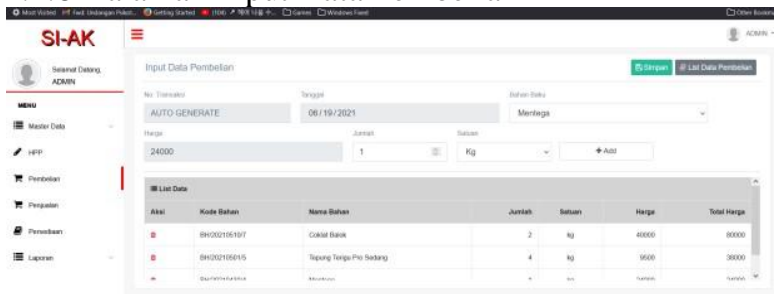

Gambar 4.7 Halaman Input Data Pembelian

Pada gambar 4.7 merupakan halaman yang berisikan form untuk menginputkan data transaksi pembelian, dimana user menginputkan nomor transaksi, tanggal, bahan baku, harga, jumlah, satuan setelah itu dapat disimpan dengan menekan tombol simpan.

\subsubsection{Halaman List Data Pembelian}

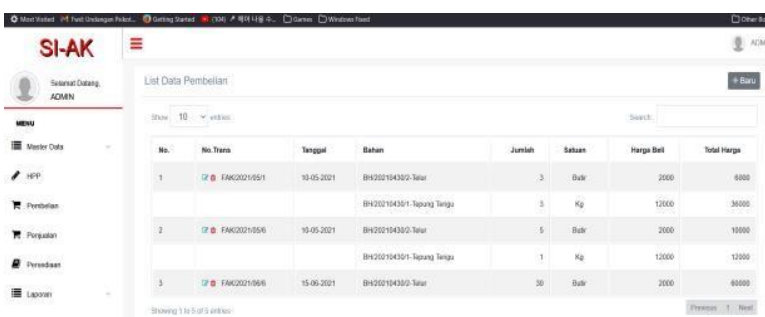

Gambar 4.8 Halaman Data Pembelian

Pada gambar 4.8 merupakan list data pembelian bahan baku yang menyimpan riwayat transaksi pembelian untuk keperluan toko dimana menyimpan informasi nomor transaksi, tanggal, bahan, jumlah, satuan, harga beli, dan total harga.

\subsubsection{Halaman Input Data Penjualan}

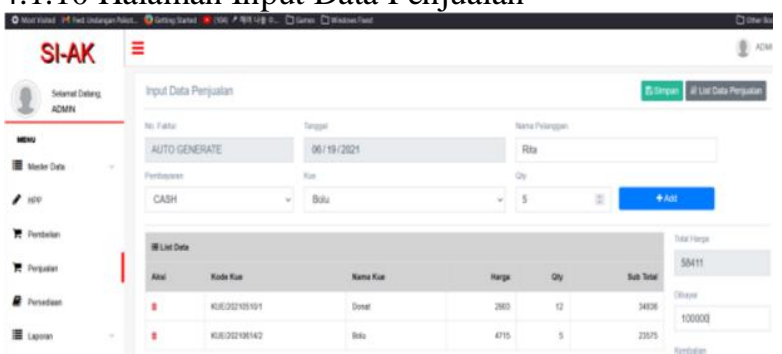

Gambar 4.9 Halaman Input Data Penjualan

Pada gambar 4.9 merupakan halaman input data penjualan. Transaksi penjualan yangg terjadi di toko kue akan dicatat ke dalam form bagian atas pada halaman ini yang terdiri atas nomor transaksi, tanggal, nama pelanggan, pembayaran, nama kue dan kuantitas yang dapat ditambahkan dengan menekan tombol $a d d$, dan otomatis masuk ke dalam list data dibagian bawah halaman.

4.1.11 Halaman List Data Penjualan

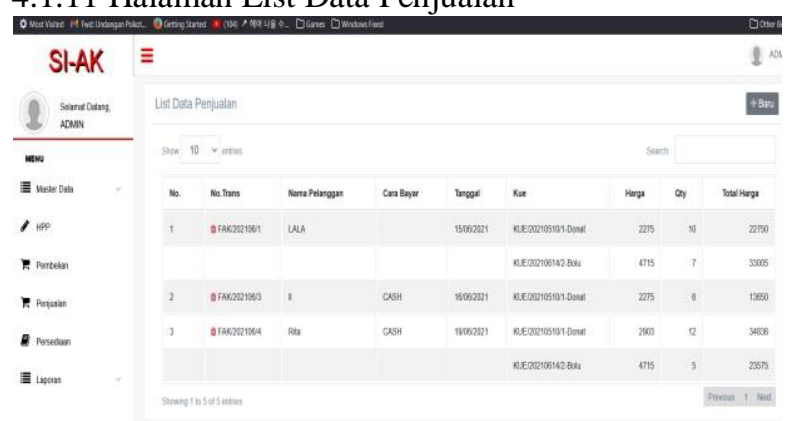

Gambar 4.10 Halaman List Data Penjualan

Pada gambar 4.10 merupakan list data penjualan yang nyimpan riwayat transaksi penjualan yang telah terjadi di toko, dimana mencakup informasi nomor transaksi, nama pelanggan, pembayaran, tanggal, kue, harga, kuantitas, dan total harga.

\subsubsection{Halaman List Persediaan Bahan}

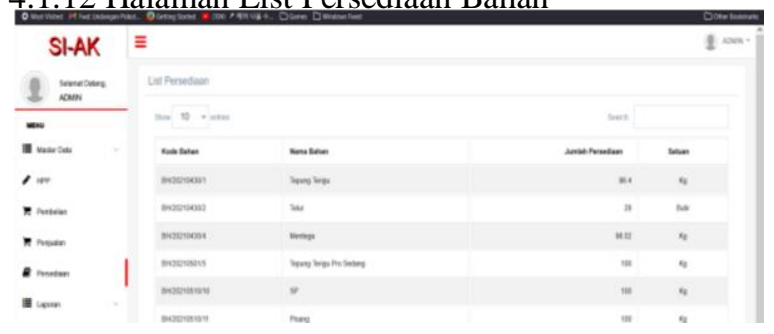

Gambar 4.11 Halaman List Persediaan Bahan

Pada gambar 4.11 merupakan list persediaan bahan baku yang mencakup informasi kode bahan, nama bahan, jumlah persediaan saat ini dan satuan.

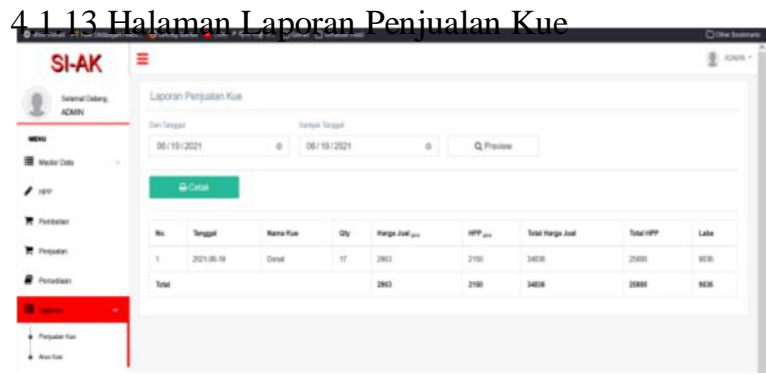

Gambar 4.12 Halaman Laporan Penjualan Kue

Pada gambar 4.12 merupakan tampilan laporan penjualan kue yang mencakup informasi tanggal, nama kue, kuantitas, harga jual, HPP, total harga jual, total HPP, dan laba. Laporan dapat dicetak dengan menekan tombol cetak.

4.1.14 Halaman Laporan Arus Kas Toko

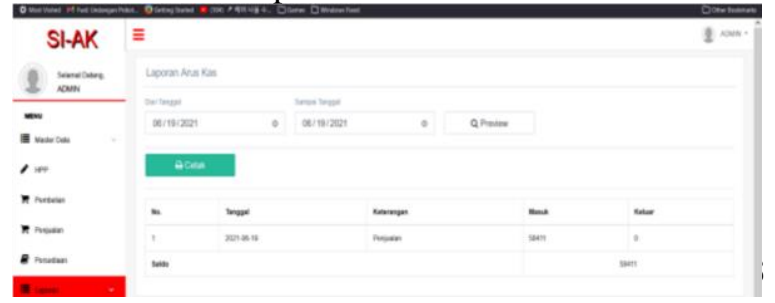


Gambar 4.13 Halaman Laporan Arus Kas

Pada gambar 4.13 merupakan tampilan laporan arus kas toko yang mencakup informasi data tanggal, keterangan, kas masuk dan kas keluar. Laporan dapat langsung dicetak dengan menekan tombol cetak.

\subsubsection{Fitur Ubah Password}

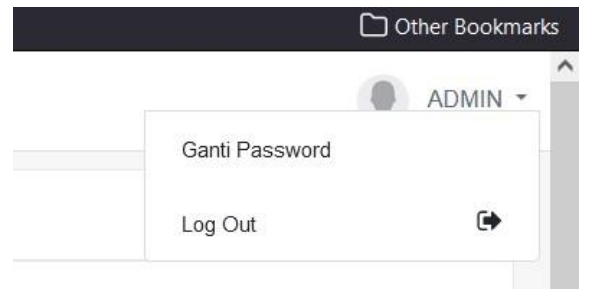

Gambar 4.14 Halaman Ubah Password

Pada gambar 4.14 diatas pengguna dapat mengganti password apabila perlu, setelah itu akan muncul form dimana pengguna harus menginputkan password sebelumnya dan juga password yang baru.

\subsection{Pengujian Fungsional}

Pengujian fungsional merupakan salah satu cara untuk melihat apakah fitur yang tersedia pada aplikasi dapat berjalan sesuai dengan harapan. Hasil pengujian fungsional aplikasi ditunjukkan pada tabel 4.1.

Tabel 4.1 Pengujian Fungsional Sistem.

\begin{tabular}{|c|l|c|c|}
\hline \multirow{2}{*}{ No } & \multicolumn{1}{|c|}{ Fungsi } & \multicolumn{2}{c|}{ Browser } \\
\cline { 3 - 4 } & \multicolumn{1}{|c|}{$\begin{array}{l}\text { Chrome } \\
\text { username dan password. }\end{array}$} & $\sqrt{ }$ & $\sqrt{ }$ \\
\hline 2 & $\begin{array}{l}\text { Admin dapat melihat tampilan } \\
\text { menu utama. }\end{array}$ & $\sqrt{ }$ & $\sqrt{ }$ \\
\hline 3 & $\begin{array}{l}\text { Admin dapat menambah, } \\
\text { mengubah, menghapus data } \\
\text { master bahan dan kue }\end{array}$ & $\sqrt{ }$ & $\sqrt{ }$ \\
\hline 4 & $\begin{array}{l}\text { Admin dapat mengubah data } \\
\text { lokasi data JNE. }\end{array}$ & $\sqrt{ }$ & $\sqrt{ }$ \\
\hline 5 & $\begin{array}{l}\text { Admin dapat memasukkan data } \\
\text { lokasi data JNE. }\end{array}$ & $\sqrt{ }$ & $\sqrt{ }$ \\
\hline 6 & $\begin{array}{l}\text { Admin dapat menghapus data } \\
\text { lokasi data JNE. }\end{array}$ & $\sqrt{ }$ & $\sqrt{ }$ \\
\hline 7 & $\begin{array}{l}\text { Admin dapat melihat titik lokasi } \\
\text { kantor JNE pada Maps. }\end{array}$ & $\sqrt{ }$ & $\sqrt{ }$ \\
\hline 8 & $\begin{array}{l}\text { Admin dapat melakukan } \\
\text { pencarian rute. }\end{array}$ & $\sqrt{ }$ & $\sqrt{ }$ \\
\hline
\end{tabular}

\subsection{Pengujian User}

Tabel 4.2 berikut adalah tabel pengujian user yang berisikan hasil dari pengujian aplikasi yang bertujuan untuk mendapatkan penilaian dari user tentang aplikasi sistem informasi akuntansi dengan metode HPP pada toko kue Rania. Dilakukan dengan membagikan kuisioner kepada 10 pengguna yang sudah menjalakan aplikasi tersebut.
Tabel 4.2 Pengujian User

\begin{tabular}{|l|c|c|c|}
\hline \multirow{2}{*}{ Pertanyaan } & & \multicolumn{2}{c|}{ Jawaban } \\
\cline { 2 - 4 } & Ya & Cukup & Tidak \\
\hline $\begin{array}{l}\text { Apakah aplikasi mudah } \\
\text { dioperasikan? }\end{array}$ & 10 & 0 & 0 \\
\hline $\begin{array}{l}\text { Apakah aplikasi dapat membantu } \\
\text { mengelola data stok bahan baku } \\
\text { dengan baik? }\end{array}$ & 7 & 3 & 0 \\
\hline $\begin{array}{l}\text { Apakah aplikasi dapat } \\
\text { membantu menentukan penentuan } \\
\text { harga jual kue? }\end{array}$ & 9 & 1 & 0 \\
\hline $\begin{array}{l}\text { Apakah aplikasi dapat membantu } \\
\text { dalam mengelola penjualan kue ? }\end{array}$ & 10 & 0 & 0 \\
\hline $\begin{array}{l}\text { Apakah semua fitur berjalan } \\
\text { dengan baik? }\end{array}$ & 10 & 0 & 0 \\
\hline
\end{tabular}

Dari pengujian user pada Tabel 4.2 diatas didapatkan data dari 10 user yang sudah di berikan pertanyaan. Pengguna harus memberikan tanda centang pada kolom yang sesuai dengan apa yang dirasakan oleh pengguna ketika mengoperasikan sistem informasi akuntansi berbasis web ini. Dapat disimpulkan bahwa seluruh fitur aplikasi sistem informasi akuntansi ini dapat berjalan seluruhnya.

\section{KESIMPULAN DAN SARAN}

\subsection{Kesimpulan}

Setelah dilakukannya pengujian pada rancang bangun sistem informasi akuntansi berbasis web menggunakan metode HPP pada toko kue Rania, maka penulis mendapatkan kesimpulan sebagai berikut :

1. Pengujian fungsional sistem dapat disimpulkan bahwa aplikasi berbasis web ini berjalan dengan baik pada beberapa browser seperti Chrome dan Mozilla.

2. Pengujian user yang telah dilakukan terhadap 10 pengguna dapat disimpulkan bahwa sistem informasi akuntasi dapat berjalan dengan baik, diantaranya dapat melakukan perhitungan HPP, dapat mengelola master data bahan kue dan stok, menampilkan laporan penjualan, dan menampilkan laporan arus kas.

3. Pengujian black-box sistem yang telah dilakukan dapat disimpulkan secara fungsional seluruh fitur sistem sudah dapat menghasilkan output yang diharapkan.

\subsection{Saran}

Sistem informasi akuntansi berbasis web menggunakan metode HPP pada toko kue Rania ini terdepat kekurangan dan kelebihan, sehingga dibutuhkan saran untuk memperbaiki sistem ini.

Berikut ini adalah saran dari penilitian yang telah dilakukan, agar dapat dikembangkan pada perangkat mobile seperti Android dan $i O S$ agar petugas lebih mudah dalam penggunaan program. 


\section{DAFTAR PUSTAKA}

[1] Hall, James. A. 2004. Sistem Informasi Akuntansi. Edisi 4.Buku 1.Diterjemahkan: Dewi Fitriasari dan Deny Arnos Kwari. Jakarta. Salemba Empat.

[2] Otinur, Faujan .2017. Analisis Sistem Informasi Akuntansi Dan Sistem Pengendalian Internal Persediaan Barang Pada Toko Campladean Mana. Jurnal Riset Akuntansi Going Concern.

[3] Nufus, Khayatun .2018. Analisis Sistem Informasi Penjualan.

[4] Mulyadi. 2010. Sistem Akuntansi. Jakarta : Salemba Empat.

[5] Andri Kristanto .2008. Perancangan Sistem Informasi dan aplikasinya. Yogyakarta : Gava Media.
[6] Jogiyanto. 2000. Sistem Informasi Berbasis Komputer. Yogyakarta : BPFE

[7] Nugroho, Widjajanto. 2001. Sistem Informasi Akuntansi. Jakarta : Erlangga

[8] Jogiyanto. 2005. Sistem Teknologi Informasi. Yogyakarta: Andi

[9] Supriyono. 2013. Akuntansi Biaya, dan Penentuan Harga Pokok. Buku Satu. Edisi Kedua. Cetakan Delapan Belas. BPFE. Yogyakarta.

[10] Putri, W.R., 2012. Artikel Mengenai Pemrograman Web. Diambil dari: http://ilmukomputer. org/wpcontent/uploads/2012/10/windapemrogramanwe b. pdf . Diakses pada 13 Maret 2021. 